\title{
Conservationists seek compromise over new threat to Galapagos
}

Munich. Conservation groups are seeking a last-minute compromise in a bill that has already been approved by Ecuador's National Congress restricting immigration to the Galapagos archipelago, but also allowing a level of economic activity that, they argue, threatens the unique biodiversity of the islands.

The law was drawn up by Eduardo Veliz, a Galapagos congressman, and approved by congress in July. But final approval by Ecuador's new president, Abdala Bucaran, has been delayed while a compromise is sought between the law's supporters and its critics.

The Galapagos islands, which inspired Charles Darwin's theory of evolution, are the world's last remaining oceanic archipelago to preserve most of its original range of individual species, or biodiversity. Ninetyseven per cent of the Galapagos was designated as a national park in the 1960 s.

The new law aims to resolve recent conflicts between conservationists and the local population. This has doubled over the last five years as a result of immigration from the mainland, and the population is expected to double again by 2010 if no action is taken.

The high level of conservation has been largely due to the efforts of the Charles Darwin Foundation, which has a research station on the islands, and the Ecuadorian national parks authority, whose stringent rules allow national park land to be used only for tourism and scientific activity.

In the past few years, however, the islands have come under enormous pressure from immigrants from the mainland seeking a better livelihood in what is now Ecuador's richest province. In addition, the Galapagos marine reserve, which was set up in 1986 to help protect marine resources, is being exploited by fishermen from all over the Pacific, threatening the survival of several species, particularly the sea cucumber, Isostichopus fuscus (see Nature 373, 465; 1995).

The law drawn up by Veliz sets up a new authority in Galapagos to administer the islands and protect the economic interests of the region and its population, which now stands at 16,000 . The Galapagos national park authority will be brought under the jurisdiction of this new authority, but will not be represented on its board.

The Charles Darwin Foundation, which acts as formal adviser to both the national park authority and the government of Ecuador on conservation issues, has welcomed some of the main changes that the law will introduce, particularly the fact that immigration will be restricted.

But it views other changes with concern, in particular the proposed reduction in status of all national parks in Ecuador, allowing "moderate human intervention". In practice this would permit the construction of infrastructure elements, such as roads, to give a boost to local agricultural activity.

Conservationists are also worried about the protection of the marine reserve. Although the law would extend its size by 40 miles from shore, there will no longer be areas designated free from economic exploitation and decisions about fishing

\section{African biology federation takes shape}

Cape Town. Plans to launch a Federation of Biochemists and Molecular Biologists for Africa are due to be announced during the First Pan-African Conference on Biochemistry and Molecular Biology in Nairobi this week.

According to Peter Campbell, professor of biochemistry and molecular biology at University College, London, the federation is intended to become a sister organization to the European, Pan-American, and Asian and Oceanic federations. Africa has until now been left out, largely because of travel restrictions that accompanied apartheid.

The concept of an African federation has the support of the United Nations Environmental Programme, which has provided facilities for the meeting. In addition, several non-African scientific societies and funding agencies have provided funds to enable biochemists from all over Africa to attend.

Wieland Gevers, deputy vice-chancellor at the University of Cape Town, and a former president of the Biochemical Society of South Africa, says there is a clear need for the continent's biochemical societies to work together. But he says that achieving this may not be easy in practice because of factors such as the large distances between countries and their serious lack of resources.

He suggests that the viability of an African federation is likely to depend on its receiving financial and organizational support from other bodies, without being dominated by them. Michael Cherry

\section{IMAGE UNAVAILABLE FOR COPYRIGHT REASONS}

No safety in numbers: human immigrants threaten Galapagos' unique biodiversity.

quotas will be taken by the government department of fisheries, without reference to conservationists.

The law also specifies that nongovernmental organizations (NGOs) should not be allowed to sell souvenirs. This is intended to allow the local population to benefit economically from tourism. But it would also require the Charles Darwin Research Station, the only NGO in the Galapagos, to close down its own shop, on which it depends for 30 per cent of its income.

Hendrik Hoeck, a former director of the Charles Darwin Research Station, and a member of the Charles Darwin Foundation's council, describes the situation in Galapagos as "very scary". Between 100 and 150 new species of animals and insects have already been introduced by migrants and fishermen, he says, upsetting the ecological balance of the islands.

"This is still the best-managed archipelago in the world, having been able to maintain around 90 per cent of its biodiversity, compared to Hawaii, which has retained only around 40 per cent," says Hoeck. But, he adds, if the current management system is destabilized and conservationists are squeezed out of the system, "the world will lose for ever an important heritage".

Richard Faust, president of the Frankfurt Zoological Society, which is one of the largest independent supporters of the Charles Darwin Foundation, has written to President Bucaran pointing out the dangers in the law, and asking him to consider the social and economic consequences of facilitating loss of biodiversity, which, by stimulating tourism, is the principal source of Galapagos's wealth.

Alison Abbott 